\title{
Trust and Distrust Determinants of Mobile Banking Adoption in the Nigerian Banking Industry: A Study of First Bank Nigeria Limited
}

\author{
Felicia Akujinma Anyanwu' ${ }^{1}$, Harrison Utum Ubi ${ }^{1}$ \\ and Amalachukwu Chijindu Ananwude ${ }^{1^{\star}}$ \\ ${ }^{1}$ Department of Banking and Finance, Nnamdi Azikiwe University, Anambra State, P.M.B. 5025, \\ Awka, Nigeria.
}

Authors' contributions

This study was carried out in collaboration between all authors. Author FAA sourced, managed relevant literature and critically reviewed the manuscript. Author HUU conceptualized the study and wrote the first draft of the manuscript. Author ACA administered and retrieved the questionnaires, performed the analysis and interpreted the results. All authors read and approved the final

manuscript.

\section{Article Information}

DOI: 10.9734/ARJASS/2017/30589

Editor(s):

(1) Isabel Negro Alousque, Faculty of Economics, Complutense University, Madrid, Spain. (2) Sarminah Samad, Faculty of Business Management, Universiti Teknologi MARA, Selangor, Malaysia.

(3) David A. Kinnunen, Department of Kinesiology, California State University Fresno, USA.

Reviewers:

(1) Darmesh Krishanan, Management and Science University(MSU), Malaysia.

(2) J. Ramola Premalatha, VIT University, India

(3) Solomon Ali Dansieh, Wa Polytechnic, Ghana.

(4) Ahmadu Abubakar, Federal University, Nigeria.

(5) Gasheja Faustin, University of Rwanda, Rwanda.

(6) Imre Ersoy, Marmara University, Turkey.

Complete Peer review History: http://www.sciencedomain.org/review-history/20121

Original Research Article

Received $20^{\text {th }}$ November 2016 Accepted $22^{\text {nd }}$ April 2017 Published $19^{\text {th }}$ July 2017

ABSTRACT

This study ascertains the trust and distrust determinants of mobile banking adoption in the Nigeria banking industry by specifically assessing the effect of perceived benefit, ease of usage, risk and monetary cost on customers' intention to adopt mobile banking. To achieve these objectives, Technology Acceptance Theory was employed using a descriptive survey research design. Using a purposive sampling technique, three hundred and forty five (345) customers were selected and questionnaires distributed accordingly. Out of 345 questionnaires distributed, 325 were fully

*Corresponding author: Email: amalision4ltd@yahoo.com; 
completed while 20 questionnaires were not fully completed and as a result were discarded. The reliability of the responses were checked using the Alpha Cronbach's test. Data were analysed using descriptive statistic, Likert scale, Pearson correlation and probit regression model. The result reveals that perceived benefit and ease of usage significantly influence and determine the behavioural intention of customers to adopt mobile banking. The finding also discloses that perceived risk and monetary cost does not deter customers from adopting mobile banking. In view of the findings, banks should vehemently and continually advance the benefits of mobile banking to customers by providing a user guide which will contain abundant details on the benefits of mobile banking, especially on the logistic/transport fee associated with accessing the banking hall for customers that are far from branch location. Banks should put in more effort to improve the ease of usage by negotiating and dialoguing with software producers to design mobile banking applications that specifically meet the need of customers.

Keywords: e-banking; perceived benefit; ease of usage; perceived risk; perceived monetary cost.

\section{INTRODUCTION}

The advent of Information and Communication Technology (ICT) in banking operations virtually led to prevalence of modern banking methods over traditional methods of banking that have been in existence in different countries for decades. The world has been labelled a global village due to advanced technology, as practically everything can be done real time online. Information and communication technology has developed to help smoothen business operations around the world, especially in the banking industry where the Automated Teller Machine (ATM) was designed to make money withdrawal easier for customers [1]. Mobile banking in the Nigeria banking industry is not as popular as in the United States of America (USA), England and other developed countries in the world. Regardless of the time saved through mobile banking, some customers of deposit money banks in Nigeria particularly the elderly, are afraid of using mobile banking because of the risk and uncertainty associated with the service. [2] noted that notwithstanding the benefits of mobile banking, the use of mobile banking services is much lower than expected in both developed and developing economies. Consequently, deposit money banks are required to play a critical role in inculcating mobile banking habits to their customers, paying attention to the security and safety of the mobile banking platform. At this point the issue of trust and distrust come into play. In the marketing process of mobile phone banking, user's trust should be strengthened while user's distrust should be weakened [3].

The banking consolidation exercise of 2005 ushered in many technology driven banking products in Nigeria. Deposit money banks have made a huge investment in mobile banking softwares and maintenance which resulted in increased volume and value of transactions on the mobile banking platform. Central Bank of Nigeria's (CBN) statistical bulletin of 2014 reports that the volume of transactions in mobile banking increased to 29, 156, 406 in 2014 against 1, 809, 251 in 2009. This means about 1, 611.52\% appreciation within a period of five years. The value of transaction increased to $\$ 119,47$ billion in 2014 as compared to $\$ 1.27$ billion in 2009 . This shows that mobile banking is gaining relevance in the banking industry. Mobile banking applications provided by the Nigerian banking industry are easily installable in mobile smart phones. Some of the top mobile banking applications in Nigeria are Firstmonie by First Bank, U-Mobile by United Bank for Africa, Stanbic's IBTC mobile money and eaZymoney by Zenith Bank [4]. Nevertheless, [3] mention problems in the process of mobile banking development such as imperfect technology, unsafe funds safeguard, system deficiencies and the relatively high costs.

Mobile technologies and services are envisioned as the possible driving force that will create a variety of business opportunities [5]. Service providers are putting in great efforts to take advantage of the business opportunities offered by wireless technology [6]. This could be adduced to the relevance of ICT banking products in current competition in the banking industry. The banking sector is critical for economic growth and development of any nation, especially developing economies like Nigeria. Hence the sector needs to align with current trends in technology products so as to efficiently and effectively contribute to growth. Banks will need to introduce changes (both at the procedural level and at the informational level) 
such as moving from traditional distribution channel to electronic distribution channel [7]. Electronic banking is beneficial to both banks and customers reduces the cost of transactions and provides convenience as everything is done on ease with a mobile gadget at the customer's earliest convenience. Mobile banking is a new element of electronic banking that, unlike traditional phone banking services, which have very limited functions, is a rich platform for automated banking and other financial services [8]. Mobile banking will reduce the cost of financial transactions for their customers, help banks to increase customer satisfaction in the way banking transactions are carried out, allow new entrants to the financial sector and also help banks to increase their sales and reduce cost [1].

\subsection{Objectives of the Study}

1. To ascertain the influence of perceived benefit on customers intention to adopt mobile banking in First Bank of Nigeria Limited.

2. To determine the influence of perceived ease of usage on customers intention to adopt mobile banking in First Bank of Nigeria Limited.

3. To assess the influence of perceived risk on customers intention to adopt mobile banking in First Bank of Nigeria Limited.

4. To evaluate the perceived monetary cost on customers intention to adopt mobile banking in First Bank of Nigeria Limited.

\subsection{Hypotheses of the Study}

1. Perceived benefit does not significantly determine customers' intention to adopt mobile banking in First Bank of Nigeria Limited.

2. Perceived ease of usage does not significantly determine customers' intention to adopt mobile banking in First Bank of Nigeria Limited.

3. Perceived risk does not significantly determine customers' intention to adopt mobile banking in First Bank of Nigeria Limited.

4. Perceived monetary cost does not significantly determine customers' intention to adopt mobile banking in First Bank of Nigeria Limited.

The structure of the paper is as follows. Section two provides a literature review (concept of mobile banking, theoretical underpinnings and empirical studies) and raison d'être for our study. Section three deals with the methodology, followed by data presentation, results and discussion. Finally, section five presents some concluding remarks and policy implications.

\section{LITERATURE REVIEW}

\subsection{Concept of Mobile Banking}

Mobile banking is a service provided by a bank or a financial institution to customers through a software called application, which allows carrying out banking transactions with the aid of a mobile enabled device such as a mobile smart phone or tablet. [9] see mobile-banking as an extension of internet banking which provides time independence, convenience, a prompt response to customers and cost savings. In the perspective of [3], mobile banking is an electronic banking innovation business using mobile network and mobile communication technology to realize connection of mobile phones and other mobile devices in the banking system and also provides a variety of financial services through the mobile interface or Short Message Service (SMS). The concept of mobile-banking is generally used to refer to the new technologies that give access to banking services via mobile phones [10]. Mobile banking is considered a subset of electronic banking which underlies not only the determinants of the banking business but also the special conditions of mobile commerce [11].

Mobile banking as offered by banks is an enriched service where customers securely, conveniently and comfortably perform banking transactions on their mobile smart phones at any point in time. Mobile banking allows the transfer of fund from one to another, check account balance and mini statement, pay bill of assorted types and airtime purchase without visiting the banking hall to have face to face contact with bank staff. Mobile banking systems provide a variety of financial services, including micropayments to merchants, bill-payments to utilities, person to person transfers, business to business transfers, business to person transfers and long-distance remittances [12]. In developed countries mobile banking services are available 24 hours per day, 7 days per week and 52 weeks per year. However, such is not the situation in Nigeria and other emerging economies in the world where network problems most times are the order of the day. The amount of fund movement through mobile banking varies from 
bank to bank. In First Bank Nigeria Plc the maximum transfer limit is $\$ 500,000.00$ while customers who have token (a personalised code for consummating transaction) can transact up to $\mathrm{N} 1,000,000.00$. This limit is applicable to virtually all other deposit money banks in the Nigerian banking industry.

\subsection{Trust and Distrust Elements Influencing Adoption of Mobile Banking}

\subsubsection{Trust elements}

Trust in a lay person's language is having confidence, reliance, fairness, honour, truth or ability of person or something. For mobile banking to appeal to customers, the element of trust is very critical. Trust is at the epicentre of financial innovative products and services usage. [3] remarked that among the factors that influence user trust in mobile banking, trust propensity belongs to internal stability factors, which include "trust belief" and "trust stand", where trust belief deals with consumers' confidence in mobile banking based on experience in dealing with banks. Trust can be expressed as the initial attitude of the individuals who lack understanding of the mobile banking system, but must decide whether to trust mobile banking software. Trust enhances customers' conviction that deposit money banks and mobile service providers will provide a worthwhile service to them via mobile banking or a similar platform. Trust enables users to believe that mobile service providers have enough ability and benevolence to provide them with useful services [13]. [3] identified four trust elements: trust tendency, consumer cognition (evaluation of ease of use and usefulness), perceived benefit and system quality. However, this study is limited to perceived benefit and ease of usage of mobile banking.

\subsubsection{Perceived ease of usage of mobile banking}

Ease of usage deals with the extent to which a customer accepts as true that the use of mobile banking should be simple. Mobile banking adoption can be influenced tremendously by ease of usage. Customers are in most cases not likely to patronize innovative financial products that are byzantine in usage and control. Mobile banking should be easy to use and get familiarized with, which in turn encourages customers to use it. A direct relationship is assumed to exist between perceived ease of use and behavioural intention of customers to adopt mobile banking. The empirical study of [14] revealed that the greater the perceived ease of use, the more likely mobile banking will be adopted by bank customers in Malaysia. If customers believe that mobile banking is easy to use then, they will use mobile banking [15]. This has been supported empirically by $[12,16]$ and [17].

\subsubsection{Perceived benefit/value of mobile banking}

Perceived benefit or value is the magnitude or degree a customer accepts as true that the usage of mobile banking will boost his/her job execution. The use of computers in the workplace will increase the user's productivity, improve job performance, and enhance job effectiveness and usefulness [14]. Once the customers realize the importance of the technology based alternative method of service delivery, the intention to adopt such services will increase [17]. In a study by [11] in India, perceived usefulness has a positive impact on the intention to adopt mobile banking. On the contrary, the findings of [18] showed no significant impact of perceived usefulness on mobile banking adoption, though it significantly impacts attitudes toward mobile banking adoption in United Arab Emirates.

\subsubsection{Distrust elements}

Distrust may be viewed as the belief that mobile banking is not reliable and should not be trusted to effectively and judiciously provide services to customers. Distrust seems to be the antonym of trust, but [3] envisaged that distrust is not the opposite of trust: a high degree of confidence is not equivalent to non-existence of distrust, low trust does not mean high level of distrust. Mobile banking adoption will not strive in customers' distrust. Rather than focusing on improving customers' trust on mobile banking, deposit money banks should also look at occurrences that present distrust to customers. This will in no small measure increase the rate of customers' adoption of mobile banking. Perceived monetary cost and risk were chosen to reflect distrust cognitive element of mobile banking adoption capable of influencing mobile banking adoption in the Nigerian banking industry. 


\subsubsection{Perceived monetary cost of mobile banking}

This is the cost linked to the use of mobile banking services. The cost can be short message service alert of mobile network providers, bank transaction charge, cost of accessing internet, etc. Perceived monetary cost affects adoption of mobile banking: the higher the perceived monetary cost, the higher the unwillingness of customers to adopt mobile banking as an alternative to traditional banking methods. Although financial innovation is associated with some costs (operation, investment, maintenance/service), by lowering the cost of mobile banking, price conscious customers will be more likely to adopt the innovation [19]. In Nigeria, each mobile banking transaction on smart phones costs $\$ 8.00$ for two short message notification alerts [one indicating your financial status as well as the monetary value of transaction performed while the other shows the charge from Nigerian Inter-Bank Settlement System Instant Payment (NIP)] and NIP and Value Added Tax (VAT) fee of N100.00 and $\$ 5.00$ respectively. Put differently, a total of N185 is charged for any transaction performed on smart phone devices. Furthermore, smart mobile phones accommodating such value added services are expensive. Furthermore, the smart phone operating system must be either Android, Windows or iphone operating system (iOS) and the mobile banking application does not work on Java phones.

\subsubsection{Perceived risk of mobile banking}

Perceived risk is one of the key factors to be taken into consideration while introducing new technology applications as there will be strong inhibitions amongst the consumers [20]. This perceived risk includes financial risk, security risk, technical risk, psychological risk, performance, time risk and social risk among others). Perceived risk refers to the uncertainty or loss that may arise by virtue of customers' use of mobile banking services. When customers are uncertain about product quality, brand and online services, they may worry about an unjustified delay in product delivery, providing person-toperson payment without receiving the product and other illegal activities and fraud [7].

\subsubsection{Mobile banking service provision in Nigeria}

Effective execution of monetary policy by the Central Bank of Nigeria and development of the economy could be enhanced by a stout payment system. The introduction of mobile telephony in Nigeria, its rapid growth and adoption and the identification of person to person payments as a practical strategy for financial inclusion have made it imperative to adopt the mobile channel as a means of driving financial inclusion of the unbanked [21]. The two methods applied by deposit money banks in provision of mobile banking services are the following:

\subsubsection{Short message service (SMS) banking}

This is where a customer performs banking transactions via exchanging SMS with the bank. When a customer requests for a particular banking service using a designated code, the bank automatically effects the command and replies back to the customer. SMS banking can be approximately separated into push type and pull type. Push type is a one-way transaction where our bank sends us information pertaining to our account via SMS while the pull type is a two-way transaction, where we send a request and the bank replies [22]. The SMS banking happens to be an unbiased mobile banking channel as it does require the download of a mobile application and its use is applicable to all types of phones, for instance, dialing *894*amount\# on any mobile phone allows the purchase of airtime from First Bank Nigeria Limited provided you have an account with the bank and funded, and the mobile number with which the call is placed is registered with the account. Nevertheless, one of the disadvantages associated with SMS banking is that customers need to know the required codes to perform such banking transactions.

\subsubsection{Wireless application protocol (WAP) based applications}

In this approach, a customer installs an application software which serves as a user interface that permits the customer to execute any banking transaction without physically visiting the banking hall. Mobile banking applications are easier to use, as customers with least effort can circumnavigate various banking transactions via menus. The activation of this mobile application requires customers to appropriately input debit/credit card details into the phone following the instructions of the bank. Some mobile applications are restricted to a particular smart phone, so that any attempt to access your account from another mobile device will involve a change in your existing Personal 
Identification Number (PIN) through Unstructured Supplementary Service Data (USSD) to authenticate the request of multiple devices. This is applicable to Eco Bank Nigeria Plc mobile banking application.

\subsubsection{Models of mobile banking}

Three models of mobile banking service provision: bank-led model, bank focused model and non-bank led model. These models are discussed below.

\subsubsection{Bank-Led model}

This model explains the situation where banks through an agreement with mobile network providers make available different banking services to customers through application and SMS. In this model, customers conduct a wide range of financial services through mobile phones instead of having a face to face conversation with bank employees. In a bank-led model, customers perform transactions with the use of their phones [19]. Customers' use and acceptance of these services creates a relationship between them and the banks. The use of this model offers banks the potential to substantially provide their services, both by extending new mobile service to their existing customers and by extending services to mobile telephony customers who do not currently have a bank account [23].

\subsubsection{Bank-Focused model}

Banks in the bank-focused model deploy low cost service delivery platforms to provide banking service to their customers. This service delivery platform may include Automated Teller Machine (ATM), Point of Sale (POS) terminal and mobile/internet banking applications to deliver a number of restricted banking services to customers. This model applies when a traditional bank decides to use the low-cost delivery channels, which is a non-traditional banking system to provide banking services to its customers such as m-banking, ATMs, internet, etc. [1].

\subsubsection{Non-Bank led model}

The non-bank led model is followed where a bank does not come into the picture (except possibly as a safe-keeper surplus fund) and the non-bank performs all the functions [24]. In other words, the telecommunication firms handle all transactions while the banks only surface when there it is necessary to safeguard surplus funds. However, mobile banking services focused on low-income customers in rural areas will need to rely on retail outlets [1].

\subsection{Theoretical Underpinnings}

In finance literature, many theories/models have been advanced to explain the determinants of technology-driven products/service adoption by customers/consumers. The most popular empirical theories are Innovation Diffusion Theory, Technology Acceptance Model and Theory of Reasoned Action. However, this study on Technology Acceptance Model.

\subsubsection{Innovation diffusion theory (IDT)}

Innovation diffusion theory elucidates the procedure by which users/consumers embrace innovation in technology. [25] defined diffusion as the process by which an innovation is communicated through certain channels over time among members of a social system. Following this definition, it can be inferred that putting in plain words in what ways novel initiatives are chosen is the nub of innovation diffusion theory. [26] considered relative advantage, compatibility, complexity, trial-ability and observability as the set of attributes linked with technological innovation that affect their rate of general acceptance. [26] also spelled out invention, diffusion (or communication) through the social system, time and consequences as the four stages in innovation diffusion process. The easiness of use and newness (in terms of persuasion, knowledge and the decision to adopt) of an innovation can determine the way an individual will respond to an innovation [1].

\subsubsection{Technology acceptance model (TAM)}

In 1989 Davies, who investigated the human behavioural intention influencing adoption of technological innovations, put forward the technology acceptance model. The model succinctly attempts to explain in what ways technology is accepted and used by customers. When users are presented with a new technological innovation, a number of elements may likely influence their decision about how and when they will use it [27]. Thus, the technology acceptance model is modelled on two essential principles: perceived usefulness/benefit and perceived ease of use of such technology innovation. According to [25], the goal of the 
technology acceptance model is to provide an explanation of the determinants of computer acceptance that is general, capable of explaining user behaviour across a broad range of end-user computing technologies and user populations, while at the same time being both parsimonious and theoretically justified. As such, the model was devised to attain these goals by identifying a small number of fundamental variables suggested by previous research dealing with the cognitive and affective determinants of computer acceptance, and using theory of reason action as a theoretical backdrop for modelling the theoretical relationships among these variables.

\subsubsection{Theory of reasoned action}

This theory was developed by Martin Fishbein and Icek Ajzen in 1980. Based on established attitudes and behavioural intents, the theory of reasoned action is concerned with how individuals behave. The theory of reasoned action focuses on the relationship between behaviours and attitudes underlying human action. Human intentions are ascertained by two factors: attitudes and subjective norms [28]. An attitude is a person's opinion about whether a behaviour is positive or negative, while a subjective norm is perceived social pressure arising from one's perception [29]. For example, Harrison's attitude as a scholar in banking and finance may embolden him to continually use mobile banking in virtually all his banking transactions, but his friends (uneducated traders in Onitsha main market) may think he is being pompous for being privileged to acquire education. If Harrison should regularly use mobile banking services, he has followed his attitude, but if he does not, he has yielded to the norms of his friend. Thus, attitudes and norms are determinants of technology innovation adoption as visualized by [28] in the theory of reasoned action.

\subsection{Empirical Studies}

\subsubsection{Empirical studies on perceived benefit and mobile banking adoption}

Hosseini et al. [8] identified the factors influencing using the mobile banking services in Saderat Bank by using the technology acceptance theory, dissuasion of innovation theory, and also advice from national banking specialists. The model divided the effective factors of the adoption of mobile banking services to the two parts: mobile banking technology characteristics and demographic characteristics. The mobile banking technology characteristics include perceptions of $m$-banking, ease of use, usefulness, cost, risk, compatibility with one's lifestyle, and need for interaction with personnel. Demographic characteristics cover gender, age, marital status, level of education, and yearly income. An empirical study was carried out on a sample of 666 people, of whom 350 people were mobile banking services users and 316 people did not use the Saderat Bank services. It was found that ease of use and need for interaction were not important for using mobile banking services from the customer's perspective. By extending the Technology Adoption Model (TAM) to incorporate the role of factors in influencing customer's perception towards M-banking adoption, [15] assessed the impact of perceived usefulness and ease of use on mobile banking adoption in Bahrain. The model was evaluated using a sample of 372 customers. The results revealed that the decision to adopt mobile banking is mainly affected by two factors: perceived usefulness and ease of use. On the other hand, some factors such as perceived cost and perceived risk did not show any effect on the users' intention to use mobile banking.

Maroofi et al. [13] analysed the effect of perceived usefulness using the Statistical Package for Social Sciences (SPSS) software. The correlation coefficient between perceived usefulness and users' choice disclosed that perceived usefulness positively affects decision to adopt mobile banking. [12] investigated the applicability of the extended Technology Acceptance Model (TAM) in determining factors that influence unbanked rural communities Zimbabwe's decision to adopt mobile banking services. A self-administered questionnaire was developed and distributed in Zaka, Chiredzi, Gutu and Chivi rural districts. Out of the 400 questionnaires, only 275 questionnaires were returned, yielding a response rate of $69 \%$. Results were subsequently analysed by the SPSS package. The findings indicated that the extended TAM can predict consumer intention to use mobile banking. Specifically, perceived usefulness, perceived ease of use, relative advantages, personal innovativeness and social norms have a significant effect on users' attitude, thus influencing the choice of mobile banking, whilst perceived risks and costs deterred users from adopting the service.

Oluoch et al. [30] examined the factors affecting adoption of M-banking technology in Nakuru 
Municipality by extending the Technology Acceptance Model (TAM). A cross-sectional survey was conducted on 163,200 bank customers, of which a sample of 399 customers was selected. Three hundred respondents returned their questionnaires. Data were analysed using descriptive statistics and the probit regression model. The study showed that perceived usefulness had a positive impact on mobile banking adoption. [7] ascertained critical success factors that influence the adoption of mobile banking in Malaysia using the extended Technology Acceptance Model (TAM). The model was empirically tested by using data collected from 300 banking users concerning their perceptions of mobile banking. The findings indicated that the model can predict consumer decision to use mobile banking. Specifically, perceived usefulness, perceived credibility and awareness about mobile banking have a significant effect on users' attitude, thus influencing the choice mobile banking.

Amin et al. [14] adopted the Technology Acceptance Model (TAM) to investigate factors that determine an individual's choice to use mobile banking among bank customers in Labuan and Kota Kinabalu. The TAM includes perceived credibility, perceived self-efficacy and normative pressure. Results support the extended TAM in predicting bank customers' intention to use mobile banking. The determinants are perceived usefulness, perceived ease of use, perceived credibility and perceived self-efficacy. Normative pressure was found to be a weak determinant in explaining bank customers' decision to use mobile banking. The study also demonstrated the significant effect of perceived ease of use on users' choice through perceived usefulness.

\subsubsection{Empirical studies on perceived ease of} usage and mobile banking adoption

Debasish and Dey [16] examined the factors that influence consumer's decision to adopt mobile banking by adopting the Technology Acceptance Model (TAM). A self-administrated questionnaire was developed and distributed in Cuttack and Bhubaneswar. Out of the 300 questionnaires, only 170 questionnaires were returned, yielding a response rate of 56.67 percent. Results were subsequently analysed using multiple regression and correlation analysis. Perceived ease of use and other factors such as perceived usefulness, relative advantages and personal innovativeness were found to be positively related with the decision to adopt mobile banking services, while perceived risks were negatively associated with mobile banking adoption.

Kazemi et al. [31] evaluated the factors that influence Isfahanian' decision to adopt mobile banking by using the Decomposed Theory of Planned Behaviour model (DTPB) and examining the effects of trust and perceived risk on users' choice. A self-administered questionnaire was developed and distributed in Isfahan city. Out of 400 questionnaires, 315 were returned $(78.0 \%)$. Of these, five responses had to be discarded due to invalid or incomplete data entries. The results showed that the crucial factors influencing mobile banking adoption are attitude and perceived behavioural control. Perceived ease of use, perceived usefulness, compatibility, and trust have a positive effect on users' attitude.

$\mathrm{Yu}$ [32] employed the unified theory of acceptance and use of technology to investigate what impacts people to adopt mobile banking. Using a sample of 441 respondents, he concluded that the decision to adopt mobile banking was significantly influenced by performance expectancy, social influence, and perceived credibility. The study also revealed that gender significantly moderated the effects of performance expectancy on the intention to adopt mobile banking, and age considerably moderated the effects of facilitating conditions and perceived self-efficacy on actual adoption of mobile banking. Integrating the Technology Acceptance Model (TAM) and the Theory of Planned Behaviour (TPB), [18] examined the effects of TAM and TPB variables on the choice of mobile banking by analysing survey data from 119 respondents. The results showed no evidence of the effect of perceived ease of use on the attitude toward mobile banking. Furthermore, the regression results showed a significant impact of perceived usefulness on attitude toward mobile banking. Surprisingly, the effects of behavioural control and usefulness on mobile banking adoption were insignificant.

Safeena et al. [11] studied the effect of perceived ease of use on the decision to adopt mobile banking. A questionnaire was developed through data collected from previous studies on acceptance of mobile banking and a convenience sampling method was used. The reliability of the method was tested using Cronbach's coefficient alpha estimate. The Cronbach's alpha values for all dimensions range from 0.60 to 0.93 , exceeding the minimum alpha 
of 0.6. The results of the study showed that perceived ease of use, perceived usefulness, consumer awareness and perceived risk determine mobile banking adoption. The study concluded that the majority of customers are accepting online banking because of many favourable factors. [33] assessed whether perceived ease of use positively influences the choice to adopt mobile banking services. The sample population consisted of 288 respondents who did not use cell phone banking services. The results demonstrated that both the value barrier and the tradition barrier had a strong negative influence on perceived usefulness. The usage barrier and the information barrier also had a strong negative influence on both perceived ease of use and the value barrier. Perceived ease of use had a strong positive influence on perceived usefulness and users' choice.

\subsubsection{Empirical studies on perceived risk and mobile banking adoption}

Achieng and Ingari [34] examined the effect of perceived risk on mobile banking adoption. They studied the way customers at the Kenyan Commercial Bank (KCB) Kilindini branch perceive the impact of cost on mobile banking adoption, and determined how perceived ease of use influenced the adoption of mobile banking. A sample of 169 respondents was used. The data were collected from account holders in KCB, Kilindini Branch. Respondents included business people, personal account holders and corporate customers. Interviews were conducted. The data were then cleaned, coded and analysed using SPSS software. The study found perceived risk to be one of the key factors impeding the adoption of mobile banking.

Alsheikh and Bojei [5] determined the major factors that influence the customer's decision to adopt mobile banking as electronic-financial services among commercial banks in Saudi Arabia. The questionnaires were distributed to samples of individuals who did not use mobile banking services in major cities in Saudi Arabia. 403 valid responses were received and analysed through multivariate analysis process using Structural Equation Modelling. The study showed perceived risk, performance expectancy and effort expectancy as major predictors for adopting mobile banking services in the initial stage. [17] studied the factors likely to influence the adoption of mobile banking services, with a special focus on the under banked/unbanked low-income population of Pakistan. The
Technology Acceptance Model (TAM) was used. The sample consisted of 372 respondents from the two largest cities (Karachi and Hyderabad) in the province of Sindh in Pakistan using the judgement sampling method. The study concluded that consumers' decision to adopt mobile banking services was significantly influenced by perceived risk, and other factors such as social influence, perceived usefulness, and perceived ease of use. The most significant positive factor was of social influence

Oluoch et al. [30] studied the relationship between perceived risk and adoption of mobile banking technology in Nakuru Municipality by extending the Technology Acceptance Model (TAM). A cross-sectional survey was conducted on 163, 200 bank customers, of whom a sample of 399 customers were selected. 300 respondents returned their questionnaires. The data were analysed using descriptive statistics and the probit regression model. The results revealed that perceived risk has a negative impact on the adoption of mobile banking. [35] identified the factors that affect mobile banking adoption in Jordan. A questionnaire containing 22 questions was used. Out of the 450 questionnaires distributed, 301 were returned. The research findings suggested that perceived risk, self-efficacy, trail-ability, compatibility, complexity and relative advantage were statistically significant in influencing mobile banking adoption.

\subsubsection{Empirical studies on perceived monetary cost and mobile banking adoption}

Hosseini et al. [8] looked into the effective factors that influence mobile banking adoption in Saderat Bank by using the Technology Acceptance Theory, the Dissuasion of Innovation Theory, and also advice from national banking specialists. Of a sample of 666 people, 350 people were mobile banking services users and 316 people did not use the Saderat Bank services. Descriptive statistics as well as statistical inference were also employed. The cost of mobile banking, compatibility variables, trial ability and profitability were ranked by customers as factors influencing the adoption of mobile banking services.

AISoufi and Ali [15] analysed the effect of perceived cost and perceived risk on mobile banking adoption in Bahrain using a sample of 372 customers. The results revealed that 
perceived cost and perceived risk did not show any effect on the users' intention to use mobile banking. The unified theory of acceptance and use of technology was employed by [32] to assess what leads people to adopt mobile banking. Through a sample of 441 respondents and reliability test performance with alpha Cronbach estimation, the study revealed that consumer intention to adopt mobile banking was significantly influenced by social factors, perceived financial cost, performance expectancy, and perceived credibility.

Liza [36] examined the factors influencing the adoption of mobile banking in Bangladesh, with a special focus on trust, perceived cost and perceived risk ( including performance risk, security/privacy risk, time risk, social risk and financial risk). The research includes the variables of the extended technology acceptance model (TAM). The data were collected from a questionnaire administered in townships around Dhaka. The study showed that customers will consider adopting mobile banking as long as it is perceived to be useful and easy to use. But the most critical factor for the customer is cost: the service should be affordable. Trust was found to be significantly negatively correlated to perceived risk.

Nyeko [37] investigated the factors contribute to the adoption of Short Message Service (SMS) banking in the West Nile region in Uganda, based on student mobile users who hold bank accounts. A questionnaire was administered to a sample of 90 graduate students from three universities. 60 questionnaires were returned, hence the response rate was $70 \%$. The results revealed that there is strong positive relationship between financial cost, quality of Internet connectivity, complexity and trial-ability as far as SMS banking adoption is concerned. The applicability of the extension of the Technology Acceptance Model (TAM) in determining factors that influence unbanked rural communities Zimbabwe's intention to adopt mobile banking services was investigated by [12]. A selfadministered questionnaire was developed and distributed in Zaka, Chiredzi, Gutu and Chivi rural districts. Out of the 400 questionnaires, only 275 questionnaires were returned, yielding a response rate of $69 \%$. Results were subsequently analysed by the SPSS package. The findings indicated that the extended TAM can predict consumer intention to use mobile banking. The study found that perceived costs and risks deterred the adoption of the service.
Kabir [38] conducted a study on the factors that influence users of banking services to use mobile banking in Bangladesh. A self-administered questionnaire was developed and distributed among the clients of two full-fledged mobile banking service providers of Bangladesh called Brac Bank Limited and Dutch Bangla Bank Limited. Out of the 100 questionnaires, only 64 questionnaires were returned, yielding a response rate of 64 percent. Results were subsequently analysed by using multiple regressions. The analysis revealed that perceived cost and time advantages are positively related with the decision to use mobile banking services. Factors such as performance risk, security/privacy risk, time risk, social risk and financial risk are found to be negatively related with the use of mobile banking.

There is a widely accepted view that information and communication technology, particularly to mobile banking services, saves time and reduces the stress linked to going to the bank in developing countries, including Nigeria. Over the years, a number of theoretical models have been developed in an attempt to identify the factors that determine individuals' adoption of technological innovations. These theories have been empirically validated. The bulk of the literature reviewed showed that the adoption of mobile banking services is significantly influenced by perceived benefit, perceived ease of use, perceived risk and perceived monetary cost. However, the research is confined to a number of countries, e.g. [32] for New Zealand and [3] for China. In Africa, some studies are available for Kenya, e.g. [19,30] and [34], and $[12,37]$ and [33] for Zimbabwe, Uganda and South Africa respectively. The only studies concerning Nigerian banking, [1] and [2] focused on consumer behaviour and barriers to mobile banking adoptions. This study bridges the gap noticed in literature by ascertaining the trust and distrust determinants of mobile banking adoption in Nigeria banking industry using branches of First Bank Nigeria Plc in Onitsha, Anambra State as a pilot study.

\subsection{Justification of the Study}

Immediately after the consolidation exercise of 2005, commercial banks now Deposit Money Banks (DMBs) developed various technology service delivery channels to attract more customers and compete favourably in the industry [39]. [40] identified mobile banking, Automated Teller Machine (ATM), Point of Sale 
(POS) and web/internet as the four basic epayment channels available in Nigeria. Despite the availability of these e-payment platforms, there are still queues in the banking hall, suggesting that these e-payment channels are largely disregarded by customers. Furthermore, the critical attitude of customers toward the security and effectiveness of these e-payment channels deters its introduction. It is thus necessary to determine the factors that influence customers' adoption of mobile banking in a developing country like Nigeria where technological innovation and mobile banking adoption is low as compared with the USA, Great Britain, China and other developed countries of the world.

Following the introduction of technology driven channels by deposit money banks, usability and adoptability by customers became the research focus. However, the bulk of studies were conducted in developed countries e.g. [32] for New Zealand, [3] for China, [41] for Malaysia, [5] for Saudi Arabia, [16] for India, [42] for Taiwan and [18] for United Arab Emirates. In Africa, several studies were carried out in Kenya e.g. $[19,30,34]$ and [43] while [12,37] and [33] focused on Zimbabwe, Uganda and South Africa respectively. In Nigeria, the only available studies, carried out by [1] and [2], focused on consumer behaviour and barriers to mobile banking adoption. This study bridged the gap in literature by identifying the trust and distrust determinants of mobile banking adoption in the Nigeria banking industry. The influence of perceived benefit, ease of usage, risk and monetary cost on customer's decision to adopt mobile banking in First Bank of Nigeria is the aim of this study. We also hypothesize that perceived benefit, ease of usage, risk and monetary cost do not determine customers' decision to adopt mobile banking in First Bank of Nigeria.

\section{METHODOLOGY}

The source of population were selected customers of First Bank Nigeria Limited residing in Onitsha, Anambra State. The data were retrieved from questionnaires administered to customers of First Bank Nigeria Plc branches in Nkrumah/Portharcout Road, Onitsha Electronic Market, Iweka Road, Nwobodo Avenue and New Market Road, Onitsha, Anambra State. The data were then used to form aggregates which were processed and the results were developed into inferential statistics. The study was conducted at First Bank Nigeria Plc branches in the city of
Onitsha, Anambra State. The choice was motivated by the bank proximity. In addition, First Bank Nigeria Limited one of the Nigerian banks that have fully computerized its operations with modern electronic banking facilities modules provides mobile banking services to its customers.

\subsection{Sample Size and Sampling Technique}

The managers of First Bank in selected branches in Onitsha gave us 25,000, 23,000, 20,000, 15,000 and 27,000 as documented numbers of customer as at the date of visit for Nkrumah/Portharcout Road, Onitsha Electronic Market, Iweka Road, Nwobodo Avenue and New Market Road branches respectively. However, it is worthy to note that it is difficult to have access to all these customers. As a result, the sample population was estimated at 2,500 customers to cover the selected branches. A sample size of 345 customers was selected following the YaroYamani sampling procedure. To select 345 respondents out of the 2,500 customers, a purposive sampling method was used in which 69 customers from each branch were chosen. This sampling technique was adopted as it conveniently aided the researcher to carefully focus on customers who provided the necessary information required to achieve the aim of this study.

\subsection{Design, Validity and Reliability of the Questionnaire}

The questionnaire drafted by the authors was first given to three lecturers (of whom two are professors and one is an associate professor) in Department of Banking and Finance and the Head Electronic Business, First Bank Nigeria Limited, to ensure that it reflected mobile banking facets as currently applicable in Nigeria. Thereafter, 15 questionnaires were administered to $10 \mathrm{PhD}$ students of Banking and Finance Department and the 5 selected branch managers of First Bank Limited, Onitsha for pre-testing to check use of words, categorization and errors. In the light of the responses, the questionnaire was modified to make it unambiguous to customers. Furthermore, the alpha Cronbach's estimation was applied to statistically check the reliability of the responses. The data collected were analysed using percentages and five-point Likert scale. The Likert was graded as 5, 4, 3, 2 and 1 point for Strongly Agreed (SA), Agreed (A), Undecided (UD), Disagreed (DA) and Strongly Disagreed (SD) respectively. Tables were used in 
presenting the data. The responses regarding the objectives and hypotheses were further analysed using ordinary least square regression estimation and Pearson correlation analysis.

\subsection{Hypothesis Decision Criteria}

If the p-value of the variable(s) concerned is less than 0.05 ( $5 \%$ level of significance), the null hypothesis is rejected and the alternate hypothesis accepted. On the other hand, if the pvalue is greater than $0.05 \quad(5 \%$ level of significance), the null hypothesis is accepted and the alternate hypothesis rejected.

\section{DATA COLLECTION, RESULTS AND DISCUSSION}

\subsection{Data Collection}

A total of three hundred and forty five (345) questionnaires containing twelve (12) questions were distributed to respondents. As shown in Fig. 1 , out of 345 questionnaires, 325 were fully completed thus showing a response rate of $94.20 \%$. 20 questionnaires (5.80\%) were not fully completed and were thus discarded.

\subsubsection{Sex distribution of respondents}

Fig. 2 displays the sex pattern of the respondents. $57 \%$ of the respondents are male while, $43 \%$ are female.

\subsubsection{Age distribution of respondents}

As shown in Fig. 3, 16\% of the respondents are between $18-25$ years, $46.15 \%$ are between 26 - 35 years, $24.31 \%$ are between $36-45$ years, while $13.54 \%$ are 46 years and over.

\subsubsection{Distribution of respondents on the basis of education}

Fig. 4 presents the educational level of respondents. $10.46 \%$ of the respondents had primary education, while $23.38 \%$ hold WAEC/SSCE and $30.77 \%$ have a Diploma/NCE, while $31.39 \%$ hold a B.Sc./HND and $4.00 \%$ a PGD/M.Sc./Ph.D.

\subsubsection{Distribution of respondents on the basis of marital status}

As we can see in Fig. 5, 52\% of the respondents are single, $39.0 \%$ are married, $0.92 \%$ divorced and $8 \%$ are widows/widowers. The high number of single customers may be attributed to the fact that majority of bank customers using mobile banking services are young.

\subsubsection{Distribution of respondents on the basis of banking experience}

Fig. 6 shows that $20.92 \%$ of the respondents have been bank customers for two years at most, $52 \%$ have been customers for $3-5$ years, $20 \%$ for $6-8$ years, while $7.08 \%$ have been bank customers for more than 9 years.

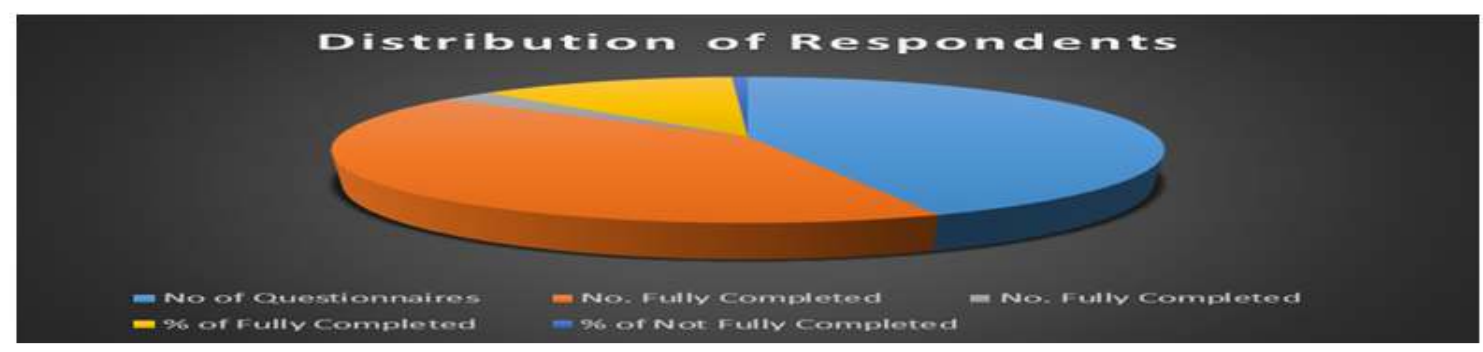

Fig. 1. Distribution of respondents Source: Field Survey October, 2016

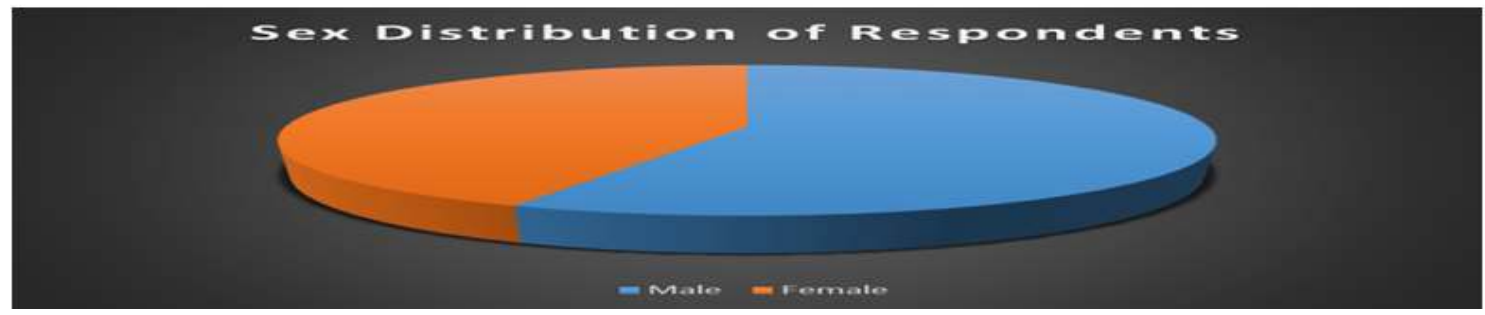

Fig. 2. Sex distribution of respondents Source: Field Survey October, 2016 


\subsubsection{Distribution of respondents on the basis of the type of bank account}

Fig. 7 shows that $59.38 \%$ of the respondents have a savings account, $28.00 \%$ have a current account, $8.62 \%$ have a fixed deposit account, and $4.00 \%$ hold the three types of account.

\subsubsection{Distribution of respondents on the basis of use of mobile banking}

Fig. 8 reveals that $25.85 \%$ of the respondents have used the mobile services provided by First Bank Nigeria Limited.

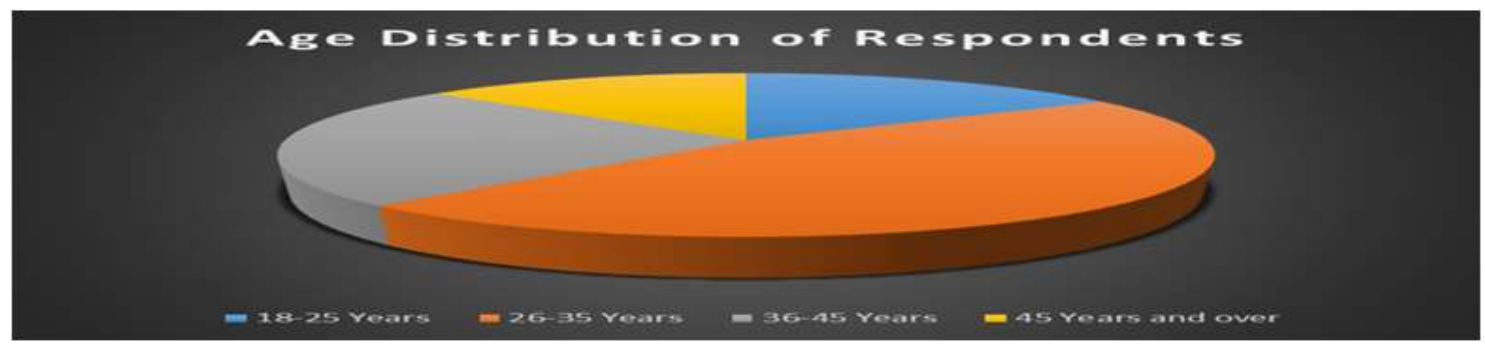

Fig. 3. Age distribution of respondents

Source: Field Survey October, 2016

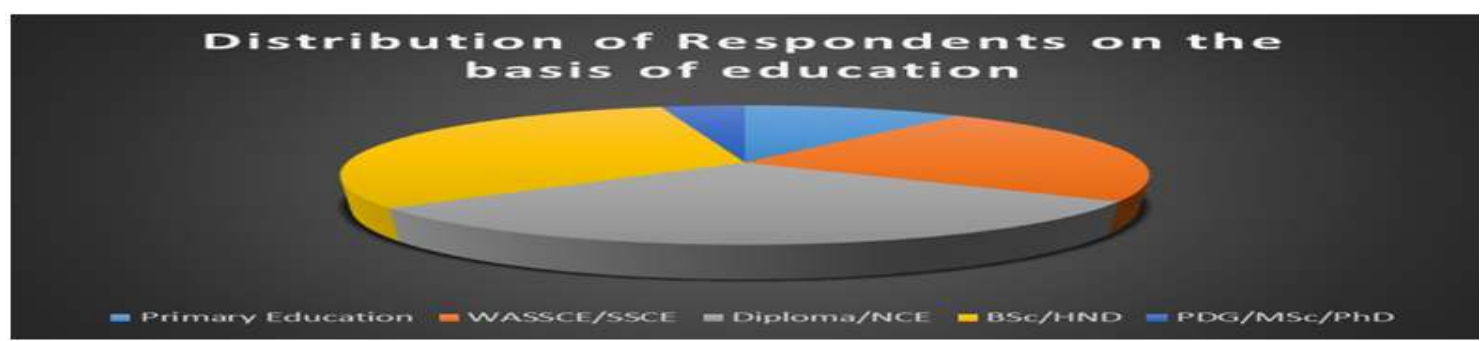

Fig. 4. Distribution of respondents on the basis of education Source: Field Survey October, 2016

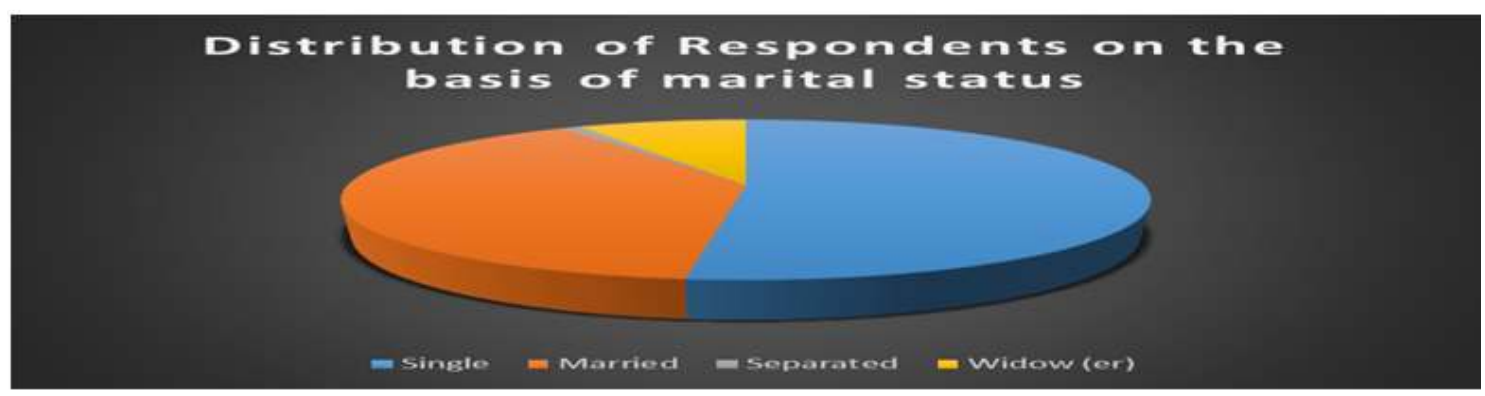

Fig. 5. Distribution of respondents on the basis of marital status Source: Field Survey October, 2016

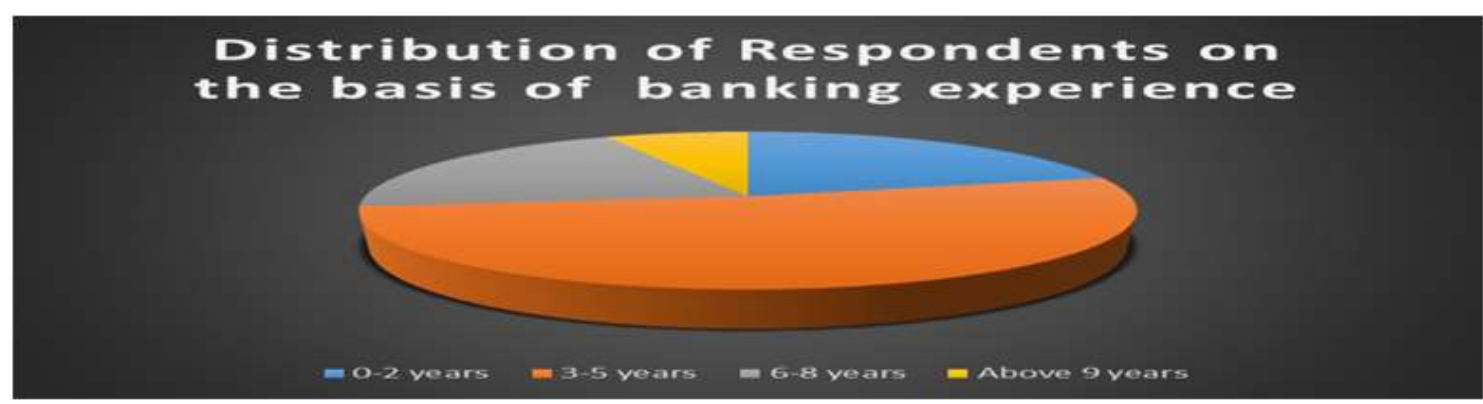

Fig. 6. Distribution of respondents on the basis of banking experience Source: Field Survey October, 2016 


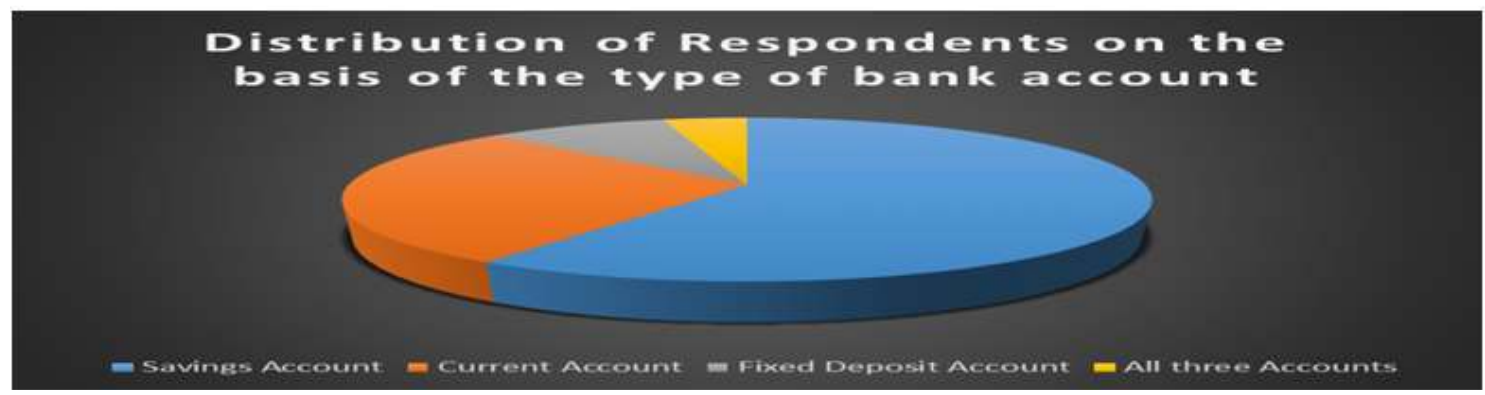

Fig. 7. Distribution of respondents on the basis of the type of bank account Source: Field Survey October, 2016

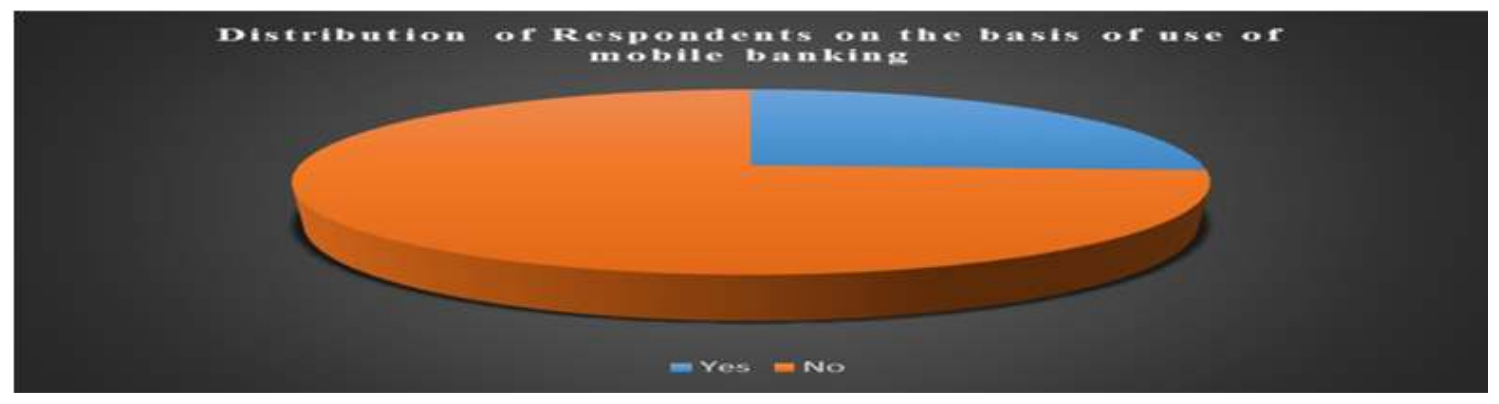

Fig. 8. Distribution of respondents on the basis of use of mobile banking Source: Field Survey October, 2016

\subsection{Alpha Cronbach's Reliability Test}

The alpha Cronbach's reliability test was conducted on the responses gathered to check for internal consistency. It yielded over 0.60 , hence all the constructs showed adequate reliability and validity. The Alpha Cronbach average score are 0.983, 0.947, 0.999, 0.998 and 0.993 for perceived benefit, ease of usage, risk, monetary cost and customer's intention respectively. Kindly see the appendix for the Alpha Cronbach for the questionnaire's items.

\subsection{Distribution of Respondents According to Trust Determinants}

\subsubsection{Distribution of respondents according to perceived benefit of mobile banking}

Regarding the respondents' level of perceived benefit of mobile banking, the study showed that the respondents' ability to take full responsibility for their bank transactions is the greatest perceived benefit with a mean score of 4.46 . This is closely followed by secrecy of financial transactions (mean score of 4.45). A large number of responses also reveals that mobile banking reduces the cost of transactions. The time saved by mobile banking services was considered the least perceived benefit; it has the lowest mean score (4.29).

\subsubsection{Distribution of respondents according to perceived ease of usage of mobile banking}

As shown in Table 2, the least effort required in executing mobile banking transaction was considered the highest ease of use provided by mobile banking with a mean of 4.61. Respondents acknowledges that mobile banking transactions are faster as compared to traditional methods. Respondents did not consider convenience and comfort associated with mobile banking as very relevant. This is reflected by the mean score of 4.20 , which is the lowest.

\subsection{Distribution of Respondents According to Distrust Determinants}

\subsubsection{Distribution of respondents according to perceived risk of mobile banking}

In terms of perceived risk, respondents considered complication in the reversal of the transaction mistakenly executed as a major 
factor against the use of mobile banking services. Secondly, the volatility of the network service in Nigeria was another perceived risk of mobile banking, as shown by a mean score of 4.46. Thirdly, a high percentage of respondents believed that the effectiveness of mobile banking is only dependent on the quality of service provided by telecommunication companies. Loss or misplacement of mobile phones is the least perceived risk in mobile banking adoption, as evidenced by a mean score of 4.27 , which is the lowest (see Table 3).

Table 1. Feedback on perceived benefit of mobile banking services

\begin{tabular}{|c|c|c|c|c|c|c|c|c|c|}
\hline Perceived benefits & SA & $\mathbf{A}$ & UD & DA & SD & TS & STD & M & $\mathbf{R}$ \\
\hline $\begin{array}{l}\text { From my point of view, mobile banking is time- } \\
\text { saving } \\
\text { Mobile banking reduces the cost of a transaction }\end{array}$ & 173 & 120 & 4 & 8 & 20 & 1,393 & 76.95 & 4.29 & $4^{\text {th }}$ \\
\hline Mobile banking improves the ability to take full & 213 & 80 & 7 & 15 & 10 & 1,446 & 88.06 & 4.44 & $3^{\text {rd }}$ \\
\hline $\begin{array}{l}\text { responsibility for my financial affairs } \\
\text { Through mobile banking, secrecy of my financial }\end{array}$ & 227 & 67 & 2 & 12 & 17 & 1,450 & 93.98 & 4.46 & $1^{\text {st }}$ \\
\hline status is maintained & 171 & 133 & 3 & 5 & 13 & 1,449 & 80.63 & 4.45 & $2^{\text {nd }}$ \\
\hline
\end{tabular}

Table 2. Feedback on perceived ease of usage of mobile banking services

\begin{tabular}{|c|c|c|c|c|c|c|c|c|c|}
\hline Perceived ease of usage & SA & $\mathbf{A}$ & UD & DA & SD & TS & STD & $\mathbf{M}$ & $\mathbf{R}$ \\
\hline $\begin{array}{l}\text { I find it easy to perform my banking } \\
\text { transactions using my mobile phone } \\
\text { application }\end{array}$ & 157 & 136 & 16 & 9 & 7 & 1,402 & 74.84 & 4.31 & $3^{\text {rd }}$ \\
\hline $\begin{array}{l}\text { My banking transactions are faster } \\
\text { when executed on my mobile phone } \\
\text { Mobile banking allows me to perform }\end{array}$ & 227 & 76 & 13 & 3 & 6 & 1,490 & 95.39 & 4.58 & $2^{\text {nd }}$ \\
\hline $\begin{array}{l}\text { my banking transactions at my earliest } \\
\text { convenience }\end{array}$ & 129 & 159 & 20 & 8 & 9 & 1,366 & 73.04 & 4.20 & $4^{\text {th }}$ \\
\hline $\begin{array}{l}\text { Banking transactions on the mobile } \\
\text { phone are carried out with the least } \\
\text { effort }\end{array}$ & 247 & 53 & 11 & 4 & 10 & 1,498 & 103.6 & 4.61 & $1^{\text {st }}$ \\
\hline
\end{tabular}

Source: Researcher's Field Survey June, 2016

Note: $S A$ = Strongly Agreed; $A=$ Agreed; $S D=S t r o n g l y$ Disagreed; $D A=$ Disagreed; UD=Undecided; $T S=T o t a l$ Score; $S T D$ Standard Deviation; $M=$ Mean and R=Rank

Table 3. Perceived risk of mobile banking services

\begin{tabular}{|c|c|c|c|c|c|c|c|c|c|}
\hline Perceived risk & SA & A & UD & DA & SD & TS & STD & $\mathbf{M}$ & $\mathbf{R}$ \\
\hline $\begin{array}{l}\text { The misplace or loss of mobile phone } \\
\text { may pose a risk to use of mobile } \\
\text { banking services }\end{array}$ & 173 & 120 & 4 & 8 & 20 & 1,393 & 76.95 & 4.27 & $4^{\text {th }}$ \\
\hline $\begin{array}{l}\text { In the process of executing a mobile } \\
\text { banking transaction, internet/server } \\
\text { connection may be lost or mobile } \\
\text { phone battery off } \\
\text { Once a mobile banking service } \\
\text { transaction is mistakenly completed }\end{array}$ & 213 & 80 & 7 & 15 & 10 & 1,446 & 88.06 & 4.45 & $2^{\text {nd }}$ \\
\hline $\begin{array}{l}\text { e.g. input of wrong account number, } \\
\text { reversal of such transaction is } \\
\text { complicated }\end{array}$ & 227 & 67 & 2 & 12 & 17 & 1,450 & 93.98 & 4.46 & $1^{\text {st }}$ \\
\hline $\begin{array}{l}\text { Banking transactions on mobile } \\
\text { phones are not reliable because their } \\
\text { effectiveness depends on the mobile } \\
\text { network used by customers }\end{array}$ & 171 & 133 & 3 & 5 & 13 & 1,419 & 80.63 & 4.37 & $3^{\text {rd }}$ \\
\hline
\end{tabular}


Table 4. Feedback on monetary cost of mobile banking services

\begin{tabular}{|c|c|c|c|c|c|c|c|c|c|}
\hline Monetary cost & SA & $\mathbf{A}$ & UD & DA & SD & TS & STD & $\mathbf{M}$ & $\mathbf{R}$ \\
\hline $\begin{array}{l}\text { The bank SMS charge of } \mathrm{A} 8.00 \text { per } \\
\text { mobile banking transaction [first SMS } \\
\text { indicating your financial status as well as } \\
\text { the monetary value of transaction } \\
\text { performed while the second SMS shows } \\
\text { the charge from Nigerian Inter-Bank } \\
\text { Settlement System Instant Payment } \\
\text { (NIP)] is high }\end{array}$ & 210 & 90 & 10 & 4 & 11 & 1,459 & 88.48 & 4.49 & $2^{\text {nd }}$ \\
\hline $\begin{array}{l}\text { The mobile network providers charge for } \\
\text { accessing the Internet to perform a } \\
\text { transaction is too high }\end{array}$ & 217 & 70 & 9 & 8 & 21 & 1,429 & 88.67 & 4.40 & $4^{\text {th }}$ \\
\hline $\begin{array}{l}\text { Smart phones allowing access to mobile } \\
\text { banking services are expensive in } \\
\text { Nigeria }\end{array}$ & 211 & 93 & 6 & 3 & 12 & 1,463 & 89.77 & 4.50 & $1^{\mathrm{st}}$ \\
\hline $\begin{array}{l}\text { The Nigerian Inter-Bank Settlement } \\
\text { System Instant Payment (NIP) charge of } \\
\text { A105.00 per mobile banking transaction } \\
\text { is on the high side. }\end{array}$ & 226 & 67 & 7 & 9 & 16 & 1,453 & 93.31 & 4.47 & $3^{\text {th }}$ \\
\hline
\end{tabular}

\subsubsection{Distribution of respondents according to perceived monetary cost of mobile banking}

As it can be seen in Table 4, respondents believed that the cost of purchasing smart phones that offer full mobile banking access is high in Nigeria, as illustrated by the highest mean of 4.50. This may be attributed to the current recession. Respondents also indicated that the bank SMS charge of $\$ 8.00$ per mobile banking transaction is high. They also expressed their displeasure about the $\$ 105.00$ fee per mobile banking transaction charged by Nigerian InterBank Settlement System, as reflected by the mean score of 4.47 .

\subsection{Distribution of Respondents According to their Attitude toward Mobile Banking}

Respondents who have used mobile banking services preferred it to traditional banking method, as shown by a mean score of 4.56 , which is the highest, followed by the user-friendly features of mobile banking applications and the respondents' attitude toward information and communication technology, with a joint mean score of 4.41. Adopting mobile banking as result of the rapid expansion in technology is the last factor with a mean of 4.26 (see Table 5).

\subsection{Pearson Correlation}

Table 6 shows the correlation between trust, distrust determinants and intention to adopt mobile banking as hypothesized by the Technology Acceptance Model. There is a positive correlation relation between customers' intention to adopt mobile banking and perceived benefit, perceived ease of use, perceived risk and perceived monetary cost. The correlation between trust, distrust determinants and intention to adopt mobile banking is statistical significant (5\%).

\subsection{OLS Regression}

\subsubsection{Perceived benefit and intention to adopt mobile banking}

Adjusted $\mathrm{R}$ squared is the coefficient which tells us the variation in the dependent variable due to changes in the independent variable. As shown in Table 7, the value of adjusted $R$ squared was 0.989 , so that there was variation of $98.90 \%$ in customers' intention to adopt mobile banking due to perceived benefit. This shows that $98.90 \%$ changes in customers' intention to adopt mobile banking may be accounted for by perceived benefit. $R$ is the correlation coefficient which shows the relationship between the variables; there was a strong positive relationship between the variables $(0.996)$. 
Table 5. Feedback on intention to adopt mobile banking

\begin{tabular}{llllllllll}
\hline Behavioural Intentions & SA & A & UD & DA & SD & TS & STD & M & R \\
\hline $\begin{array}{l}\text { My attitude toward ICT prompted my } \\
\text { adoption of mobile banking for my } \\
\text { banking transactions }\end{array}$ & 193 & 108 & 2 & 7 & 15 & 1,432 & 83.76 & 4.41 & $2^{\text {nd }}$ \\
$\begin{array}{l}\text { I find mobile banking services more } \\
\text { user-friendly than customer service in } \\
\text { the banking hall }\end{array}$ & 222 & 68 & 3 & 9 & 23 & 1,432 & 91.38 & 4.41 & $2^{\text {nd }}$ \\
$\begin{array}{l}\text { I prefer using mobile banking services } \\
\text { to queuing in the banking hall }\end{array}$ & 230 & 77 & 1 & 5 & 12 & 1,483 & 97.31 & 4.56 & $1^{\text {st }}$ \\
$\begin{array}{l}\text { I am certain that mobile banking } \\
\text { adoption is valuable and should be } \\
\text { adopted for future bank transactions }\end{array}$ & 187 & 99 & 2 & 11 & 26 & 1,385 & 79.18 & 4.26 & $4^{\text {th }}$ \\
\hline
\end{tabular}

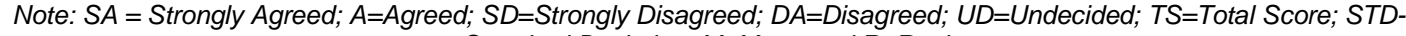
Standard Deviation; $M=$ Mean and R=Rank

Table 6. Correlation between trust, distrust determinants and intention to adopt mobile banking

\begin{tabular}{|c|c|c|c|c|c|c|}
\hline & & Intention & $\begin{array}{l}\text { Perceived } \\
\text { benefit }\end{array}$ & $\begin{array}{l}\text { Perceived } \\
\text { ease of use }\end{array}$ & $\begin{array}{l}\text { Perceived } \\
\text { risk }\end{array}$ & $\begin{array}{l}\text { Perceived } \\
\text { monetary } \\
\text { cost }\end{array}$ \\
\hline \multirow[t]{3}{*}{ Intention } & Pearson Correlation & 1 & .996 & .986 & .997 & .998 \\
\hline & Sig. (2-tailed) & & .000 & .002 & .000 & .000 \\
\hline & $\mathrm{N}$ & 5 & 5 & 5 & 5 & 5 \\
\hline Perceived & Pearson Correlation & $.996^{* \pi}$ & 1 & $.995^{* *}$ & $.999^{* \pi}$ & $.989^{* \pi}$ \\
\hline \multirow[t]{2}{*}{ Benefit } & Sig. (2-tailed) & .000 & & .000 & .000 & .001 \\
\hline & $\mathrm{N}$ & 5 & 5 & 5 & & 5 \\
\hline Perceived & Pearson Correlation & $.986^{\star \star}$ & $.995^{\wedge \pi}$ & 1 & $.992^{* \pi}$ & $.980^{* *}$ \\
\hline Ease of & Sig. (2-tailed) & .002 & .000 & & .001 & .003 \\
\hline Use & $\mathrm{N}$ & 5 & 5 & 5 & 5 & 5 \\
\hline Perceived & Pearson Correlation & $.997^{\star x}$ & $.999^{x *}$ & $.992^{* *}$ & 1 & $.992^{x *}$ \\
\hline \multirow[t]{2}{*}{ Risk } & Sig. (2-tailed) & .000 & .000 & .001 & & .001 \\
\hline & $\mathrm{N}$ & 5 & 5 & 5 & 5 & 5 \\
\hline Perceived & Pearson Correlation & $.998^{\star x}$ & $.989^{* \pi}$ & $.980^{* \pi}$ & $.992^{x \pi}$ & 1 \\
\hline Monetary & Sig. (2-tailed) & .000 & .001 & .003 & .001 & \\
\hline Cost & $\mathrm{N}$ & 5 & 5 & 5 & 5 & 5 \\
\hline
\end{tabular}

Source: SPSS 22.0 Data Output

Table 7. Model summary

\begin{tabular}{lllll}
\hline Model & R & R square & Adjusted R square & Std. error of the estimate \\
\hline 1 & $.996^{\mathrm{a}}$ & .991 & .989 & 9.33215 \\
\hline \multicolumn{5}{c}{ Source: SPSS 22.0 Data Output }
\end{tabular}

From the ANOVA statics in Table 8, the value of significance ( $p$-value) is less than $5 \%$, which means that the data are suitable to draw a conclusion on the population parameters.

Table 9 reveals that if the perceived benefit is constant, customers' intention to adopt mobile banking would be -2.79 . There is a positive and significant relationship between customers' intention to adopt mobile banking and perceived benefit. Perceived benefit coefficient of 0.996 suggests that a unit increase in perceived benefit would result in a 0.996 factor increase in customers' intention to adopt mobile banking.

\subsubsection{Perceived ease of usage and intention to adopt mobile banking}

From the regression outcome in the Table 10 the value of adjusted $R$ squared was 0.962 . This means that there was fluctuation of $96.2 \%$ on customer's intention to adopt mobile banking as a result of perceived ease of usage. This shows that $96.2 \%$ changes in customer's intention to adopt mobile banking was attributed to perceived ease of usage. There is a strong positive relationship between customers' intention to adopt mobile banking and perceived ease of usage, as shown by 0.986 . 
Table 8. ANOVA

\begin{tabular}{llllll}
\hline Model & Sum of squares & df & Mean square & F & Sig. \\
\hline 1 Regression & 30050.733 & 1 & 30050.733 & 345.058 & $.000^{\mathrm{b}}$ \\
Residual & 261.267 & 3 & 87.089 & & \\
Total & 30312.000 & 4 & & & \\
\hline \multicolumn{7}{r}{}
\end{tabular}

Table 9. Coefficients

\begin{tabular}{|c|c|c|c|c|c|}
\hline \multirow[t]{2}{*}{ Model } & \multicolumn{2}{|c|}{$\begin{array}{c}\text { Unstandardized } \\
\text { coefficients }\end{array}$} & $\begin{array}{l}\text { Standardized } \\
\text { coefficients }\end{array}$ & \multirow[t]{2}{*}{$t$} & \multirow[t]{2}{*}{ Sig. } \\
\hline & B & Std. error & Beta & & \\
\hline $\begin{array}{ll}1 & \text { (Constant) } \\
& \text { Perceived Benefit }\end{array}$ & $\begin{array}{l}-2.785 \\
1.043\end{array}$ & $\begin{array}{l}5.544 \\
.056\end{array}$ & 996 & $\begin{array}{l}-.502 \\
18.576\end{array}$ & $\begin{array}{l}.650 \\
.000\end{array}$ \\
\hline
\end{tabular}

Table 10. Model summary

\begin{tabular}{lllll}
\hline Model & $\mathbf{R}$ & R square & Adjusted R square & Std. error of the estimate \\
\hline 1 & $.986^{\text {a }}$ & .971 & .962 & 16.99346 \\
\hline \multicolumn{5}{c}{ Source: SPSS 22.0 Data Output }
\end{tabular}

Table 11. ANOVA

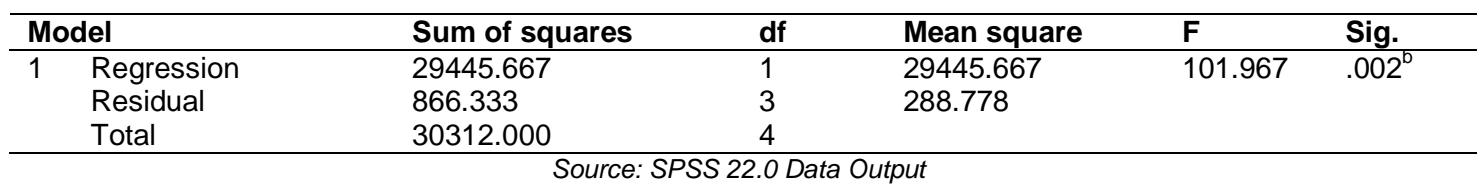

Table 12. Coefficients

\begin{tabular}{|c|c|c|c|c|c|}
\hline \multirow[t]{2}{*}{ Model } & \multicolumn{2}{|c|}{$\begin{array}{c}\text { Unstandardized } \\
\text { coefficients }\end{array}$} & $\begin{array}{l}\text { Standardized } \\
\text { coefficients }\end{array}$ & \multirow[t]{2}{*}{$t$} & \multirow[t]{2}{*}{ Sig. } \\
\hline & B & Std. error & Beta & & \\
\hline $\begin{array}{ll}1 & \text { (Constant) } \\
& \text { Perceived Ease of Usage }\end{array}$ & $\begin{array}{l}-3.471 \\
1.053\end{array}$ & $\begin{array}{l}10.185 \\
.104\end{array}$ & 986 & $\begin{array}{l}-.341 \\
10.098\end{array}$ & $\begin{array}{l}.756 \\
.002\end{array}$ \\
\hline
\end{tabular}

The value of significance ( $p$-value) of the data in Table 11 is less than $5 \%$, which means that the data are suitable to draw a conclusion on the population parameters. Furthermore, the $\mathrm{F}$ statistic of 101.97 is statistically significant $(2 \%$ level of significance).

Table 12 shows that there is a positive and significant relationship between customers' intention to adopt mobile banking and perceived ease of usage. The coefficient of the constant means that the customer's intention to adopt mobile banking would be 0.121 , perceived ease of usage being constant. The perceived ease of use coefficient of 0.986 reveals that an increase in perceived ease of usage would result in a 0.986 factor increase in customers' intention to adopt mobile banking.

\subsubsection{Perceived risk and intention to adopt mobile banking}

As it can be seen in Table 13 the value of adjusted $\mathrm{R}$ squared is 0.992 , an indication that there was a variation of $99.2 \%$ on customer's intention to adopt mobile banking due to perceived risk. $\mathrm{R}$, the correlation coefficient, shows there is a strong positive relationship between customers' intention to adopt mobile banking due to perceived risk, as reflected by 0.997 .

From the ANOVA statics in Table 14, the value of significance ( $p$-value) is less than $5 \%$, which means that the data are suitable to draw a conclusion on the population parameters. 
Table 15 reveals that being perceived risk constant, customer's intention to adopt mobile banking would be -2.887 . There is a positive and significant relationship between customers' intention to adopt mobile banking and perceived risk. Perceived risk coefficient of 0.997 suggests that a unit increase in perceived risk would result in 0.997 factor increase in customers' intention to adopt mobile banking.

\subsubsection{Perceived monetary cost and intention to adopt mobile banking}

From the regression outcome in Table 16 the value of adjusted $R$ squared was 0.993 . This means that there was a fluctuation of $99.3 \%$ in customers' intention to adopt mobile banking as a result of perceived monetary cost. This shows that $99.3 \%$ changes in customer's behavioural intention to adopt mobile banking was attributed to perceived monetary cost. The correlation coefficient expressed as $R(0.986)$ shows there is a strong positive relationship between customers' intention to adopt mobile banking and perceived monetary cost.

The value of significance ( $p$-value) of the data in Table 17 is less than $5 \%$, which means that the data are suitable to draw a conclusion on the population parameters. Furthermore, the Fstatistic of 607.71 is statistically significant $(1 \%$ level of significance).

Table 13. Model summary

\begin{tabular}{lllll}
\hline Model & R & R square & Adjusted R square & Std. error of the estimate \\
\hline 1 & $.997^{\text {a }}$ & .994 & .992 & 7.66000 \\
\hline
\end{tabular}

Table 14. ANOVA

\begin{tabular}{llllll}
\hline Model & Sum of squares & df & Mean square & F & Sig. \\
\hline 1 Regression & 30135.973 & 1 & 30135.973 & 513.603 & $.000^{\mathrm{b}}$ \\
Residual & 176.027 & 3 & 58.676 & & \\
Total & 30312.000 & 4 & & & \\
\hline \multicolumn{5}{r}{} & Source: SPSS 22.0 Data Output
\end{tabular}

Table 15. Coefficients

\begin{tabular}{lllllll}
\hline \multirow{2}{*}{ Model } & \multicolumn{2}{l}{ Unstandardized coefficients } & Standardized coefficients & \multirow{2}{*}{ S } & & \\
\cline { 3 - 5 } & & B & Std. error & Beta & & \\
\hline 1 & (Constant) & -1.887 & 4.522 & & -.417 & .705 \\
& Perceived Risk & 1.029 & .045 & .997 & 22.663 & .000 \\
\hline
\end{tabular}

Table 16. Model summary

\begin{tabular}{lllll}
\hline Model & R & R square & Adjusted R square & Std. error of the estimate \\
\hline 1 & $.998^{\text {a }}$ & .995 & .993 & 7.04516 \\
\hline \multicolumn{5}{c}{ Source: SPSS 22.0 Data Output }
\end{tabular}

Table 17. ANOVA

\begin{tabular}{|c|c|c|c|c|c|c|}
\hline \multicolumn{2}{|c|}{ Model } & Sum of squares & df & Mean square & $\mathbf{F}$ & Sig. \\
\hline 1 & Regression & 30163.097 & 1 & 30163.097 & 607.707 & $.000^{6}$ \\
\hline & Residual & 148.903 & 3 & 49.634 & & \\
\hline & Total & 30312.000 & 4 & & & \\
\hline
\end{tabular}

Source: SPSS 22.0 Data Output

Table 18. Coefficients

\begin{tabular}{|c|c|c|c|c|c|}
\hline \multirow[t]{2}{*}{ Model } & \multicolumn{2}{|c|}{ Unstandardized coefficients } & \multirow{2}{*}{$\begin{array}{l}\text { Standardized } \\
\text { coefficients } \\
\text { Beta }\end{array}$} & \multirow[t]{2}{*}{$t$} & \multirow[t]{2}{*}{ Sig. } \\
\hline & B & Std. error & & & \\
\hline $\begin{array}{ll}1 & \text { (Constant) } \\
& \text { Perceived Ease of Usage }\end{array}$ & $\begin{array}{l}2.144 \\
.967\end{array}$ & $\begin{array}{l}4.053 \\
.039\end{array}$ & .998 & $\begin{array}{l}.529 \\
24.652\end{array}$ & $\begin{array}{l}.633 \\
.000\end{array}$ \\
\hline
\end{tabular}


Table 18 shows that there is a positive and significant relationship between customers' intention to adopt mobile banking and perceived monetary cost. The coefficient of the constant means that the customer's intention to adopt mobile banking would be 0.121 , perceived monetary cost being constant. The perceived monetary cost coefficient of 0.998 reveals that a percentage increase in perceived monetary cost would result in 0.998 factor increase in customers' intention to adopt mobile banking.

\subsection{Discussion of Findings}

The regression result in Table 9 shows that there is a positive and statistically significant relationship between perceived benefit and customers' intention to adopt mobile banking. This implies that perceived benefit has a significant influence on customers' intention to adopt mobile banking. This finding is in line with the Technology Acceptance Model (TAM), which suggests that perceived benefit affects the adoption of technology innovations. This supports the findings of $[15,12]$ and [7] on the positive impact of perceived benefit on mobile banking adoption in Bahrain, Zimbabwe and Malaysia respectively. It is also in line with the works of $[8,13,14]$ and [30].

Perceived ease of use and customer's behavioural intention to adopt mobile banking are positively and significantly related. This is indication that perceived ease of use has significant influence on customer's behavioural intention to adopt mobile banking. This again confirm the Technology Acceptance Model (TAM) using descriptive survey design from Nigeria. This result is in unison with previous studies: [18,31,11] and [33]. On the other hand it disagrees with the finding of [18] on no significant influence of perceived ease of use on customer's behavioural intention to adopt mobile banking.

Perceived risk does not negatively influence customers' intention to adopt mobile banking, as evidenced by the positive significant relationship between perceived risk and customers' intention. This may be attributed to the fact that customers using mobile banking are fully aware of how it works and how to securely execute banking transactions on mobile phone devices. This is in line with the result of [15] for Bahrain. On the contrary, it is not consistent with the research done by of $[34,5,17]$ and [35] for Kenya, Saudi Arabia, Pakistan and Jordan respectively.
Perceived monetary cost was not found to negatively influence customers' intention to adopt mobile banking, as shown by the positive and significant relationship between perceived monetary cost and customers' intention. This may be due to the fact that the transport fares to access the banking hall for most customers are high as compared to internet and bank charges on mobile banking transactions. This confirms [37] claim about the positive relationship between perceived financial cost and customer intention to adopt mobile banking in Uganda. Nevertheless, it is inconsistent with other previous research in the subject matter - [42], [36] and [15].

\subsection{Test of Hypotheses}

\subsubsection{Hypothesis one}

$\mathbf{H}_{\mathbf{0}}$ : Perceived benefit does not significantly influence customers' intention to adopt mobile banking in First Bank of Nigeria Limited.

Table 19 shows that perceived benefit determines customers' intention to adopt mobile banking in First Bank of Nigeria. Thus the null hypothesis that perceived benefit of mobile banking does not significantly determine customers' intention to adopt mobile banking in First Bank of Nigeria Limited is rejected on the ground that the $p$-values of perceived benefit is significant ( $5 \%$ level of significance).

\subsubsection{Hypothesis two}

$\mathbf{H}_{\mathbf{o}}$ : Perceived ease of use does not significantly influence customers' intention to adopt mobile banking in First Bank of Nigeria Limited.

It is crystal clear from Table 20 that perceived ease of use significantly influences customers' intention to adopt mobile banking. As a result, the null hypothesis that perceived ease of usage of mobile banking does not significantly influence customers' intention to adopt mobile banking in First Bank of Nigeria Limited is rejected.

\subsubsection{Hypothesis three}

$\mathbf{H}_{0}$ : Perceived risk does not significantly influence customers' intention to adopt mobile banking in First Bank of Nigeria Limited.

Perceived risk determines customers' intention to adopt mobile banking. Consequently, the null hypothesis that perceived risk does not significantly influence customers' intention to 
Table 19. Coefficients

\begin{tabular}{|c|c|c|c|c|c|}
\hline \multirow[t]{2}{*}{ Model } & \multicolumn{2}{|c|}{ Unstandardized coefficients } & \multirow{2}{*}{$\begin{array}{l}\text { Standardized coefficients } \\
\text { Beta }\end{array}$} & \multirow[t]{2}{*}{$\mathbf{t}$} & \multirow[t]{2}{*}{ Sig. } \\
\hline & B & Std. error & & & \\
\hline $1 \quad \begin{array}{l}\text { (Constant) } \\
\text { Perceived } \\
\text { Benefit }\end{array}$ & $\begin{array}{l}-2.785 \\
1.043\end{array}$ & $\begin{array}{l}5.544 \\
.056\end{array}$ & .996 & $\begin{array}{l}-.502 \\
18.576\end{array}$ & $\begin{array}{l}.650 \\
.000\end{array}$ \\
\hline
\end{tabular}

Table 20. Coefficients

\begin{tabular}{|c|c|c|c|c|c|}
\hline \multirow[t]{2}{*}{ Model } & \multicolumn{2}{|c|}{ Unstandardized coefficients } & \multirow{2}{*}{$\begin{array}{l}\text { Standardized } \\
\text { coefficients } \\
\text { Beta } \\
\end{array}$} & \multirow[t]{2}{*}{$t$} & \multirow[t]{2}{*}{ Sig. } \\
\hline & B & Std. error & & & \\
\hline $\begin{array}{ll}1 & \text { (Constant) } \\
& \text { Perceived Ease of Usage }\end{array}$ & $\begin{array}{l}-3.471 \\
1.053\end{array}$ & $\begin{array}{l}10.185 \\
.104\end{array}$ & .986 & $\begin{array}{l}-.341 \\
10.098 \\
\end{array}$ & $\begin{array}{l}.756 \\
.002 \\
\end{array}$ \\
\hline
\end{tabular}

Table 21. Coefficients

\begin{tabular}{|c|c|c|c|c|c|}
\hline \multirow[t]{2}{*}{ Model } & \multicolumn{2}{|c|}{ Unstandardized coefficients } & \multirow{2}{*}{$\begin{array}{l}\text { Standardized } \\
\text { coefficients } \\
\text { Beta } \\
\end{array}$} & \multirow[t]{2}{*}{$\mathbf{t}$} & \multirow[t]{2}{*}{ Sig. } \\
\hline & B & Std. error & & & \\
\hline $\begin{array}{ll}1 & \text { (Constant) } \\
& \text { Perceived Risk } \\
\end{array}$ & $\begin{array}{l}-1.887 \\
1.029 \\
\end{array}$ & $\begin{array}{l}4.522 \\
.045 \\
\end{array}$ & .997 & $\begin{array}{l}-.417 \\
22.663 \\
\end{array}$ & $\begin{array}{l}.705 \\
.000 \\
\end{array}$ \\
\hline
\end{tabular}

Table 22. Coefficients

\begin{tabular}{|c|c|c|c|c|c|}
\hline \multirow[t]{2}{*}{ Model } & \multicolumn{2}{|c|}{$\begin{array}{c}\text { Unstandardized } \\
\text { coefficients }\end{array}$} & \multirow{2}{*}{$\begin{array}{l}\text { Standardized } \\
\text { coefficients } \\
\text { Beta } \\
\end{array}$} & \multirow[t]{2}{*}{$t$} & \multirow[t]{2}{*}{ Sig. } \\
\hline & B & Std. error & & & \\
\hline $\begin{array}{ll}1 & \text { (Constant) } \\
& \text { Perceived Monetary Cost }\end{array}$ & $\begin{array}{l}2.144 \\
.967\end{array}$ & $\begin{array}{l}4.053 \\
.039\end{array}$ & .998 & $\begin{array}{l}529 \\
24.652 \\
\end{array}$ & $\begin{array}{l}.633 \\
.000\end{array}$ \\
\hline
\end{tabular}

adopt mobile banking in First Bank of Nigeria Limited is rejected on the ground that the p-value of perceived benefit is significant ( $5 \%$ level of significance).

\subsubsection{Hypothesis four}

$\mathbf{H}_{\mathbf{o}}$ : Perceived monetary cost does not significantly influence customers' intention to adopt mobile banking in First Bank of Nigeria Limited.

Perceived monetary cost significantly influence customers' intention to adopt mobile banking. As a result, the null hypothesis that perceived monetary cost does not significantly influence customers' intention to adopt mobile banking in First Bank of Nigeria Limited is rejected.

\section{CONCLUSION IMPLICATIONS \\ AND \\ POLICY}

The expansion in information and communication technology has led to the introduction of many technology driven products, especially in the banking sector. This has resulted in the increasing use of mobile phones and wireless devices. About $80 \%$ of students in tertiary institutions in Nigeria have smart phones with Internet access. Surprisingly, such upsurge in mobile phones use has not lead to increased mobile banking adoption. In the present article we have attempted to identify the factors that influence adoption of mobile banking in the Nigerian banking industry. Perceived usefulness, perceived ease of use, perceived risk and perceived monetary cost are significant determinants of mobile banking adoption in the Nigerian banking industry. Consequently, the study concludes that the Technology Acceptance Model (TAM) is applicable.

The following suggestions are put forward for consideration and implementation by banks' management.

- Banks should advance the benefit of mobile banking to customers by providing 
a user guide which explains the benefits of mobile banking, especially concerning the transport fee associated with accessing the banking hall for customers that live far away.

- Banks should put in more effort to improve ease of use by negotiating with software producers to design mobile banking applications that meet the needs of customers.

- Notwithstanding the fact that customers did not view perceived risk as a discouraging factor from mobile banking adoption, banks should put in place more security features, so that customers feel secured and protected when performing bank transactions on mobile phones.

- $\quad$ Although perceived monetary cost seems not to deter customers from adopting mobile banking, the cost per transaction should be cut so as to encourage more customers to use mobile banking services. Banks should collaborate with Nigerian Inter-Bank Settlement System to reduce the current charge of $\$ 105$ per transaction to a range of $\# 10$ to $\$ 40$. The SMS charge of $\$ 4$ each for Nigerian Inter-Bank Settlement System and available account balance on customers' account from bank should be merged as one SMS alert.

\section{COMPETING INTERESTS}

Authors have declared that no competing interests exist.

\section{REFERENCES}

1. Adesinasi BF. Mobile banking adoption and consumer behaviour in Nigeria. A thesis submitted to the Department of business and finance, London School of business and finance; 2012.

2. Agwu ME, Atum, O, Ikpefan OA, lyoha OF. Adoption triggers and barriers of mobile banking services in Nigeria. International Review of Social Sciences. 2014;2(9):374386.

3. Yao H, Liu S, Yuan Y. A study of user adoption factors of mobile banking services based on the trust and distrust perspective. International Business and Management. 2013;6(2):9-14. DOI:10.3968/j.ibm.1923842820130602.10 40.
4. Moneyissues. Top ten mobile banking applications in Nigeria; 2016.

Available: moneyissues.ng

(Accessed $25^{\text {th }}$ June, 2016)

5. Alsheikh L, Bojei J. Determinants affecting customer's intention to adopt mobile banking in Saudi Arabia. International Arab Journal of e-Technology. 2014;3(4):210219.

6. Laukkanen T. Determinants of mobile banking resistance: A preliminary model; 2009.

Available: www.ssrn.com

(Accessed 14 ${ }^{\text {th }}$ April, 2016)

7. Daud NM, Kassim NEM, Said WSR, Noor, MMM. Determining critical success factors of mobile banking adoption in Malaysia. Australian Journal of Basic and Applied Sciences. 2011;5(9):252-265.

8. Hosseini MH, Fatemifar A, Rahimzadeh M. Effective factors of the adoption of mobile banking services by customers. Kuwait Chapter of Arabian Journal of Business and Management Review. 2015;4(6):1-13.

9. Govender I, Sihlali W. A study of mobile banking adoption among university students using an extended TAM. Mediterranean Journal of Social Sciences. 2014;5(7):451-459.

10. Fall FS, Ky Y, Birba Q. Analysing the mobile-banking adoption process among low-income populations: A sequential logit model. Economic Bulletin. 2015;35(4): 2085-2103.

11. Safeena $R$, Date $H$, Kammani $H$, Hundewale N. Technology Adoption and Indian consumers: Study on mobile banking. International Journal of Computer Theory and Engineering. 2012;4(6):10201024.

12. Chitungo SK, Munongo S. Extending the technology acceptance model to mobile banking adoption in rural Zimbabwe. Journal of Business Administration and Education. 2013;3(1):51-79.

13. Maroofi F, Kahrarian F, Dehghani M. An investigation of initial trust in mobile banking. International Journal of Academic Research in Business and Social Sciences. 2013;3(9):394-403.

DOI: $10.6007 /$ IJARBSS/v3-i9/228

14. Amin $H$, Baba $R$, Muhammad MZ. An analysis of mobile banking acceptance by Malaysian customers. Sunway Academic Journal. 2007;4:1-12.

15. AlSoufi A, Ali H. Customers' perception of m-banking adoption in kingdom of Bahrain: 
An empirical assessment of an extended TAM model. International Journal of Managing Information Technology. 2014; 6(1):1-13.

16. Debasish SS, Dey S. Factors affecting adoption of mobile banking: An empirical study in the State of Odisha. International Journal f Management \& Business Studies. 2015;5(2):15-20.

17. Kazi AK, Mannan MA. Factors affecting adoption of mobile banking in Pakistan: Empirical evidence; Munich Personal RePEc Archive; 2013.

Available:http://mpra.ub.unimuenchen.de/47922

(Accessed $25^{\text {th }}$ June, 2016)

18. Aboelmaged MG, Gebba TR. Mobile banking adoption: An examination of technology acceptance model and theory of planned behaviours. International Journal of Business Research and Development. 2013;2(1):35-50.

19. Cudjoe AG, Anim PA, Nyanyofio JGNT. Determinants of mobile banking adoption in the Ghanaian banking industry: A case of access bank Ghana Limited. Journal of Computer and Communications. 2015;3:119.

20. Malhorta R. Factors affecting the adoption of mobile banking in New Zealand. A thesis submitted to the Department of Information Technology, Massey University, New Zealand; 2011.

21. Central Bank of Nigeria. Statistical bulletins; 2014.

Available: www.cenbank.gov.ng

(Accessed 30 $0^{\text {th }}$ May, 2016)

22. Chandran R. Pros and cons of mobile banking. International Journal of Scientific and Research Publications. 2014;4(10):15.

23. Mathew M, Sulphey MM, Prabhakaran J. Perceptions and intentions of customers towards mobile banking adoption. Journal of Contemporary Management Research, 2014;8:83-101.

24. Meena RS. Mobile banking and upcoming technonology in banking sphere; 2014. Available:https://books.google.com.ng/boo $\mathrm{ks} ? \mathrm{id}=\mathrm{kOJYBnlZTDQC \& pg=PA107 \& \textrm {pg } = P}$ A107\&dq=bank+focused+model+of+mobil e+banking\&source=bl\&ots=TxBYOPgErO\& sig=b4VSYRX cDa1kQEKnHngDrcdiNU\& $\mathrm{hl}=$ en\&sa $=X \&$ redir esc $=\mathrm{y} \# \mathrm{v}=$ onepage $\& \mathrm{q}=$ bank\%20focused\%20model\%20of\%20mo bile\%20banking\&f=false

(Accessed $31^{\text {st }}$ May, 2016)
25. Baraghani NS. Factors influencing the adoption of internet banking. A thesis submitted to the Department of business administration and social sciences, Lulea University of technology; 2008.

26. Rogers EM. Diffusion of innovation. $4^{\text {th }}$ Edition, New York, the Free Press; 1995.

27. Davies FD. Perceived usefulness, perceived ease of usage and user acceptance of Information and Communication Technology (ICT). MIS Quarterly. 1989;13(3):319-340.

DOI: 10:23071249008

28. Ajzen L, Fishbein M. Understanding attitudes and predicting social behaviour, Prentice-Hall; 1980.

29. Colman A. Theory of Reasoned Action. In a dictionary of psychology. $4^{\text {th }}$ Edition, London, Oxford University Press; 2015.

30. Oluoch RA, Abaja PO, Mwangi JW, Githeko J. Factors affecting adoption of mobile banking technology in Kenya: A case of bank customers within Nakuru Municipality. Asian Journal of Business and Management Sciences. 2012;2(11):113.

31. Kazemi A, Nilipour A, Kabiry N, Hoseini MM. Factors affecting Isfahanian mobile banking adoption based on the Decomposed Theory of Planned Behaviours. International Journal of Academic Research in Business and Social Sciences. 2013;3(7):230-245.

32. Yu C. Factors affecting individuals to adopt mobile banking: Empirical evidence from the UTAUT model. Journal of Electronic Commerce Research. 2012;13(2):104-121.

33. Rammile $\mathrm{N}$, Nel J. Understanding resistance to cell phone banking adoption through the application of the technology acceptance model (TAM). African Journal of Business Management. 2012;6(1):8697.

34. Achieng BM, Ingari BK. Factors influencing the adoption of mobile banking in Kenya's commercial banks: A case of Kenya Commercial Bank (KCB) Kilindini branch. International Journal of Scientific and Research Publications. 2015;5(10):1-14.

35. Khraim SH, AL-Shoubaki YE, Khraim AS. Factors affecting Jordanian consumers' adoption of mobile banking services. International Journal of Business and Social Science. 2011;2(20):96-105.

36. Liza FY. Factors influencing the adoption of mobile banking: Perspective 
Bangladesh. Global Disclosure of Economics and Business. 2014;3(3):92112.

37. Nyeko JS, Moya M, Kabaale E, Odongo J. Factors influencing the Short Message Service (SMS) mobile banking adoption: A users' perspective in the West Nile region in Uganda. European Journal of Business and Management. 2014;6(5):34-45.

38. Kabir MR. Factors influencing the usage of mobile banking: Incident from a developing country. World Review of Business Research. 2013;3(3):96-114.

39. Nwakoby CIN, Ananwude AC. The nexus between downsizing and financial performance of selected commercial banks in Nigeria: A comparative and an empirical exploration. Asian Journal of Economics, Business and Accounting. 2016;1(1):1-14. DOI: 10.9734/AJEBA/2016/28925.

40. Ibenta SNO, Anyanwu FA. Financial innovation and efficiency on the banking sub-sector. The case of deposit money banks and selected instruments of electronic banking (2006-2014). Asian Journal of Economics, Business and Accounting. 2016;1(3):1-13.

DOI: 10.9734/AJEBA/2016/29982

41. Al-Fahim NH. An exploratory study of factors affecting the internet banking adoption: a qualitative study among postgraduate students. Global Journal of Management and Business Research Finance. 2013;13(8):23-32.

42. Yu S. Factors influencing the use of mobile banking: The case of SMS-based mobile banking. A thesis submitted to Department of computer and information sciences, Auckland University of Technology; 2009.

43. Ndumba HW, Muturi W. Factors affecting adoption of mobile banking in Kenya; Case study of Kenya Commercial Bank Limuru. International Journal of Social Sciences Management and Entrepreneurship. 2014; 1(3):92-112. 


\section{APPENDIX}

\section{Alpha Cronbach reliability test result for questionnaire items}

\begin{tabular}{|c|c|c|}
\hline Construct & Items & $\begin{array}{l}\text { Alpha } \\
\text { Cronbach }\end{array}$ \\
\hline \multirow{5}{*}{$\begin{array}{l}\text { Perceived } \\
\text { Benefit }\end{array}$} & From my point of view, mobile banking is time-saving & \multirow{5}{*}{0.983} \\
\hline & Mobile banking reduces the cost of a transaction & \\
\hline & $\begin{array}{l}\text { Mobile banking improves the ability to take full responsibility for my } \\
\text { financial affairs }\end{array}$ & \\
\hline & Through mobile banking, secrecy of my financial status is maintained & \\
\hline & $\begin{array}{l}\text { I find it easy to perform my banking transactions using my mobile } \\
\text { phone application }\end{array}$ & \\
\hline \multirow{5}{*}{$\begin{array}{l}\text { Perceived } \\
\text { Ease of } \\
\text { Use }\end{array}$} & My bank transactions are faster when executed on my mobile phone & \multirow{5}{*}{0.947} \\
\hline & $\begin{array}{l}\text { Mobile banking allows me to perform my banking transactions at my } \\
\text { earliest convenience }\end{array}$ & \\
\hline & $\begin{array}{l}\text { Banking transactions on the mobile phone are carried out with the least } \\
\text { effort }\end{array}$ & \\
\hline & $\begin{array}{l}\text { The loss of mobile phone may pose a risk to use of mobile banking } \\
\text { services }\end{array}$ & \\
\hline & $\begin{array}{l}\text { In the process of executing a mobile banking transaction, } \\
\text { internet/server connection may be lost or mobile phone battery off }\end{array}$ & \\
\hline Perceived & Once a mobile banking service transaction is mistakenly completed & \multirow{4}{*}{0.999} \\
\hline \multirow[t]{3}{*}{ Risk } & $\begin{array}{l}\text { e.g. input of wrong account number, reversal of such transaction is } \\
\text { complicated }\end{array}$ & \\
\hline & $\begin{array}{l}\text { Banking transactions on mobile phones are not reliable because their } \\
\text { effectiveness depends on the mobile network used by customers }\end{array}$ & \\
\hline & The bank SMS charge of $\mathrm{N} 8.00$ per mobile banking transaction [first & \\
\hline \multirow{6}{*}{$\begin{array}{l}\text { Perceived } \\
\text { Monetary } \\
\text { Cost }\end{array}$} & SMS indicating your financial status as well as the monetary value of & \multirow{6}{*}{0.998} \\
\hline & transaction performed while the second SMS shows the charge from & \\
\hline & Nigerian Inter-Bank Settlement System Instant Payment (NIP)] is high & \\
\hline & $\begin{array}{l}\text { The mobile network providers charge for accessing the Internet to } \\
\text { perform a transaction is too high }\end{array}$ & \\
\hline & $\begin{array}{l}\text { Smart phones allowing access to mobile banking services are } \\
\text { expensive in Nigeria }\end{array}$ & \\
\hline & $\begin{array}{l}\text { The Nigerian Inter-Bank Settlement System Instant Payment (NIP) } \\
\text { charge of } 105.00 \text { per mobile banking transaction is on the high side. } \\
\text { My attitude toward ICT prompted my adoption of mobile banking for my } \\
\text { banking transactions }\end{array}$ & \\
\hline \multirow{3}{*}{$\begin{array}{l}\text { Behavioural } \\
\text { Intention }\end{array}$} & I find mobile banking services more user-friendly than customer & \multirow{4}{*}{0.993} \\
\hline & $\begin{array}{l}\text { service in the banking hall } \\
\text { I prefer using mobile banking services to queuing in the banking hall }\end{array}$ & \\
\hline & $\begin{array}{l}\text { I am certain that mobile banking adoption is valuable and should be } \\
\text { adopted for future bank transactions }\end{array}$ & \\
\hline \multicolumn{2}{|r|}{ Source: SPSS 22.0 Data Output } & \\
\hline \multicolumn{3}{|c|}{$\begin{array}{l}\text { (0) } 2017 \text { Anyanwu et al.; This is an Open Access article distributed under the terms of the Creative Commons Attribution License } \\
\text { (http://creativecommons.org/licenses/by/4.0), which permits unrestricted use, distribution, and reproduction in any medium, } \\
\text { provided the original work is properly cited. }\end{array}$} \\
\hline \multicolumn{3}{|c|}{$\begin{array}{l}\text { Peer-review history: } \\
\text { The peer review history for this paper can be accessed here: } \\
\text { http://sciencedomain.org/review-history/20121 }\end{array}$} \\
\hline
\end{tabular}

